\title{
SISTEM PENDUKUNG KEPUTUSAN UNTUK PEMILIHAN KOMPUTER DENGAN METODE BROWN GIBSON
}

\author{
I Made Aditya Virgiawan \\ Prodi Sistem Komputer, STMIK-STIKOM, Denpasar \\ ictbalicomputer@gmail.com
}

\begin{abstract}
Decision Support System is an interactive system that supports decision in the decisionmaking process through the alternatives - alternatives obtained from the processing of data, information and design models. The results provided by the system as a decision support can provide alternative solutions to problems for users by providing a range of possible results in accordance with the conditions of the problem parameters that can be changed.

Creating a Decision Support System online, using the method of Brown Gibson, is able to resolve the issue of election for selecting computer, the steps of this method are simple, easy to understand, effective and efficient. Brown Gibson methods chosen because each computer has a different character or condition, in estab-further discussion will be referred to as factors. These factors will affect the calculation to re-determine the computers that will be selected. With the web-based decision support system will be the technology that not only provides convenience, butis able provide solutions to someone in the right laptop mememilih and also suits your needs and budget .

Procedures and steps that must be taken to apply the method of Brown Gibson in this study can be described as follows: (1) elimination of any alternative site on the face of the computer that is clearly not feasible and feasible to be chosen, for example the price of computers that exceed the budget. (2) Calculate and set performance measurement of ob-yektif factor (OFI) for each alternative. With the web-based decision support system is going to be a technology that not only provides convenience, but is able to provide a solution to someone in choosing the right computer and also according to the needs and budgets.
\end{abstract}

Keywords : System, Decision Support, Brown Gibson

\begin{abstract}
ABSTRAK
Sistem Pendukung Keputusan merupakan suatu sistem interaktif yang mendukung keputusan dalam proses pengambilan keputusan melalui alternatif -alternatif yang diperoleh dari hasil pengolahan data, informasi dan rancangan model. Hasil yang diberikan oleh sistem sebagai pendukung keputusan dapat memberikan alternatif pemecahan masalah bagi pengguna dengan memberikan berbagai kemungkinan hasil sesuai dengan kondisi parameter masalah yang dapat berubah.

Pembuatan suatu Sistem Pendukung Keputusan secara online dengan menggunakan metode Brown Gibson mampu menyelesaikan untuk persoalan pemilihan komputer ini, dengan langkah-langkah metode ini yang sederhana, mudah dipahami, efektif dan efisien. Metode Brown Gibson dipilih karena setiap komputer memiliki karakter atau kondisi yang berbeda, dalam pembahasan selanjutnya akan disebut sebagai faktor-faktor. Faktor-faktor ini akan berpengaruh pada perhitungan untuk me-nentukan komputer yang akan dipilih.

Prosedur dan langkah-langkah yang harus ditempuh untuk mengaplikasikan metode Brown Gibson dalam penelitian ini dapat diuraikan sebagai berikut : (1) Eliminasi setiap alternatif site komputer yang secara sepintas jelas tidak layak dan feasible untuk dipilih, misalkan harga komputer yang melebihi anggaran. (2) Hitung dan tetapkan performance measurement dari faktor ob-yektif (OFi) untuk setiap alternatif pilihan. Dengan adanya sistem pendukung keputusan berbasis web ini akan menjadi teknologi yang tidak hanya memberikan kemudahan, namun mampu memberikan solusi kepada seseorang dalam memilih komputer yang tepat dan juga sesuai dengan kebutuhan dan anggaran.
\end{abstract}

Kata Kunci : System, Decision Support, Brown Gibson 


\section{PENDAHULUAN}

Pada era sekarang, teknologi informasi sangat berkembang dengan pesat, seiring dengan perkembangan teknologi informasi maka berkembang pula pemakaian perangkat lunak di dalam segala bidang kehidupan di masyarakat, bentuk-bentuk pemakaian sistem kerja dengan komputer juga menjadi semakin berkembang. Sistem kerja dengan komputer tidak lagi hanya di gunakan sekedar untuk mengolah data dan menyajikan informasi, namun hasil dari proses yang diolah dapat juga digunakan untuk mendukung pemecahan suatu masalah atau pendukung pengambilan keputusan dengan berbagai alternatif yang tersedia.

Hasil yang diberikan oleh sistem sebagai pendukung keputusan dapat memberikan alternatif pemecahan masalah bagi pengguna dengan memberikan berbagai kemungkinan hasil sesuai dengan kondisi parameter masalah yang dapat berubah. Hal ini akan menghasilkan berbagai alternatif pemecahan masalah yang ada, sehingga keputusan yang dibuat menjadi lebih baik dan lebih mudah. Karena itu, dibutuhkan suatu analisis untuk mendukung pengambilan keputusan dalam menentukan pemilihan komputer yang dapat menghasilkan keputusan dari berbagai alternatif yang ada dalam memilih suatu produk komputer.

Dalam rancang bangun sistem pendukung keputusan untuk pemilihan komputer ini akan menggunakan metode Brown Gibson dalam memberikan kemudahan dan mem-bantu konsumen dalam pengambilan ke-putusan untuk pemilihan komputer.

\section{TINJAUAN PUSTAKA}

\section{Pengertian Sistem}

Konsep dasar sistem menurut Jogiyanto dalam buku yang berjudul Analisis dan desain sistem informasi bahwa, terdapat dua kelompok pendekatan didalam pendefinisian sistem, yaitu yang menekankan pada prosedurnya dan menekankan pada komponen atau elemennya.

Pendekatan sistem yang lebih menekankan pada prosedur menurut Jogiyanto (2005 : 1) "Sistem adalah suatu jaringan kerja dari prosedur-prosedur yang saling berhubungan, berkumpul bersama - sama un-tuk melakukan suatu kegiatan atau untuk menyelesaikan suatu sasaran yang tertentu". Pendekatan sistem yang merupakan jaringan kerja dari prosedur lebih menekankan urutan operasi dalam sebuah sistem.

Pendekatan sistem yang lebih menekankan pada elemen atau komponennya menurut Jogiyanto (2005: 2) "Sistem adalah kumpulan dari elemen-elemen yang berinteraksi untuk mencapai suatu tujuan tertentu". Dilihat dari dua pengertian diatas maka, pengertian sistem dapat diartikan sebagai suatu kumpulan, himpunan, unsur, komponen atau variabel yang terorganisir, saling berinte-raksi, saling bergantung satu sama lain, dan terpadu untuk mencapai tujuan atau sasaran tertentu.

\section{Sistem Pendukung Keputusan}

Konsep Sistem Pendukung Keputusan (SPK) / Decision Support Sistem (DSS) pertama kali diungkapkan pada awal tahun 1970-an oleh Michael S. Scott Morton dengan istilah Management Decision Sistem. Sistem tersebut adalah suatu sistem yang berbasis komputer yang ditujukan untuk membantu pengambil keputusan dengan memanfaatkan data dan model tertentu untuk memecahkan berbagai persoalan yang tidak terstruktur.

Istilah SPK mengacu pada suatu sistem yang memanfaatkan dukungan komputer dalam proses pengambilan keputusan. Untuk mem-berikan pengertian yang lebih mendalam, diuraikan beberapa difinisi mengenai SPK yang dikembangkan oleh beberapa ahli, di-antaranya oleh Man dan Watson yang memberikan definisi sebagai berikut, SPK merupakan suatu sistem yang interaktif, yang membantu pengambil keputusan melalui penggunaan data dan model-model keputusan untuk memecahkan masalah yang sifatnya semi terstruktur maupun yang tidak terstruktur.

\section{Pengertian Metode Brown Gibson}

Metode Brown Gibson dikembangkan oleh P. Brown dan D. Gibson pada tahun 1972. Metode Brown Gibson dikembangkan dengan cara mengkombinasikan antara faktor obyektif dan faktor subyektif (Hutabarat, 2005:15). Metode Brown Gibson dipilih karena setiap komputer memiliki karakter atau kondisi yang berbeda, dalam pem-bahasan selanjutnya akan disebut sebagai faktor-faktor.

Faktor-faktor ini akan berpengaruh pada perhitungan untuk menentukan komputer yang akan dipilih. Faktor-faktor tersebut digolongkan menjadi dua macam, yaitu faktor obyektif dan faktor subyektif. 
Selan-jutnya akan dikombinasikan dan menda-patkan pilihan komputer yang memiliki nilai terbesar sebagai komputer terpilih. Faktor yang bersifat subyektif merupakan faktor faktor yang berkaitan dengan spesifikasi komputer tersebut. Sedangkan faktor obyektif ditentukan berdasarkan perkiraan biaya yang harus dikeluarkan dan dibayar untuk pembelian komputer tersebut.

Metode ini digunakan untuk menganalisis alternatif pilihan yang dikembangkan berdasarkan konsep Preference Of Measurement yang bisa mengkombinasikan faktor obyektif dan subyektif. Metode Brown Gibson biasa digunakan untuk pengambilan keputusan yang memiliki multi attribute. (Ammrapala and Luxhoj, 2000).

Prosedur dan langkah-langkah yang harus ditempuh untuk mengaplikasikan metode Brown Gibson secara garis besar dapat di-uraikan sebagai berikut : (1) Eliminasi setiap alternatif site komputer yang secara sepintas jelas tidak layak dan feasible untuk dipilih, misalkan harga komputer yang melebihi anggaran. (2) Hitung dan tetapkan performance measurement dari faktor obyektif (OFi) untuk setiap alternatif pilihan. Ukuran performance untuk faktor obyektif dihitung berdasarkan estimasi seluruh biaya yang relevan dengan total biaya yang akan dikeluarkan pada pembelian komputer (Ci) untuk setiap pilihan yang dipertimbangkan.

$$
\left.O F i=\left(C i . \sum_{i=1}^{n}\left(\frac{1}{c i}\right)\right)^{-1} \ldots \ldots \ldots . .1\right)
$$

Dimana : $\sum O F i=1$

Dengan menentukan faktor-faktor yang lebih bersifat subyektif pada saat menetapkan alternatif pilihan. Estimasi dari ukuran performance faktor subyektif (SFi) untuk setiap pilihan ditentukan dengan menggu-nakan rumus :

$$
S F i=\sum_{i=1}^{n}(W j . R i j)
$$

Dimana : $\sum S F i=1$

Keterangan :

$\mathrm{i}$ = banyaknya pilihan

$\mathrm{j}=$ banyaknya faktor

subyektif $=1,2,3, \ldots . n$

$\mathrm{Wj}=$ rating faktor dengan menggunakan forced choice pairwise comparision.
Rij = ranking faktor subyektif dari masingmasing alternatif pilihan

$$
\left(0 \leq R i j \geq 1 \text { dan } \sum R i j=1\right)
$$

Cara forced choice pairwise comparision pada prinsipnya adalah membandingkan dan menilai suatu faktor subyektif terhadap faktor subyektif yang secara berpasangan (pairwise) dengan didasarkan pada :

Tabel 1. Keterangan Nilai Bobot Faktor Subyektif

\begin{tabular}{|c|c|c|}
\hline $\begin{array}{c}\text { Nilai } \\
\text { Bobot }\end{array}$ & $\begin{array}{c}\text { Faktor } \\
\text { Subyektif } \\
\text { Pertama }\end{array}$ & $\begin{array}{c}\text { Faktor } \\
\text { Subyektif } \\
\text { Pertama }\end{array}$ \\
\hline $\begin{array}{c}\text { Lebih } \\
\text { Baik }\end{array}$ & Bernilai 1 & Bernilai 0 \\
\hline $\begin{array}{c}\text { Sama } \\
\text { Baik }\end{array}$ & Bernilai 1 & Bernilai 1 \\
\hline $\begin{array}{c}\text { Sama } \\
\text { Jelek }\end{array}$ & Bernilai 0 & Bernilai 0 \\
\hline $\begin{array}{c}\text { Lebih } \\
\text { Jelek }\end{array}$ & Bernilai 0 & Bernilai 1 \\
\hline
\end{tabular}

Untuk pembobotan, mana yang lebih diper-timbangkan, antara variabel faktor obyektif (bobot $=\mathrm{k}$ ) dengan faktor subyektif (bobot $=1-\mathrm{k}$ ) dimana $0<\mathrm{k}<$ akan menghasilkan location preference measure (LPMi) untuk setiap alternatif pilihan yang ada.

$$
\mathrm{LPMi}=[\mathrm{k} .(\mathrm{OFi})]+[(1-\mathrm{k}) \cdot(\mathrm{SFi})]
$$

$$
\text { Dimana : } \sum L P M i=1
$$

Keputusan diambil berdasarkan alternatif pilihan yang memiliki nilai LPMi terbesar.

\section{ANALISA DAN PERANCANGAN SISTEM}

Tahap analisa dan perancangan sistem ini akan membahas mengenai analisa dan pe-rancangan pembuatan sistem ini. Dalam pe-rancangan sistem ini penulis mempergunakan Macromedia Dreamweaver MX 2004 sebagai media untuk pembuatan website, sedangkan untuk perancangan database sebagai media penyimpanan data (database) penulis menggunakan $M y S Q L$ dan sebagai webserver akan digunakan Apache.

\section{Sistem Flow}

Dapat dilihat dari Gambar 1 yaitu Flowchart Program, dimulai dengan user mengisi daftar user terlebih dahulu, lalu user 
memilih kriteria budget dan kebutuhan yg diinginkan oleh user, setelah itu akan tampil tes pertanyaan dan selanjutnya user akan meng-inputkan jawaban dari data tes tersebut. Jika input berhasil maka data akan diolah dengan proses brown gibson, kemudian akan ditampilkan komputer yang cocok sesuai tes yang dilakukan oleh user.

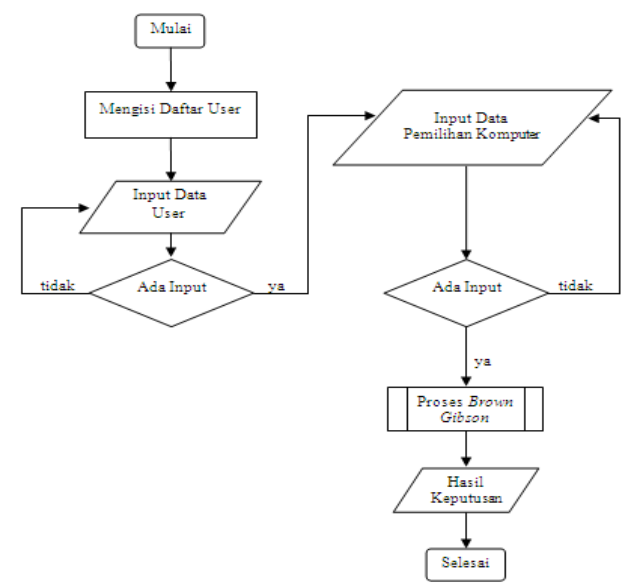

Gambar 1. Flowchart Program

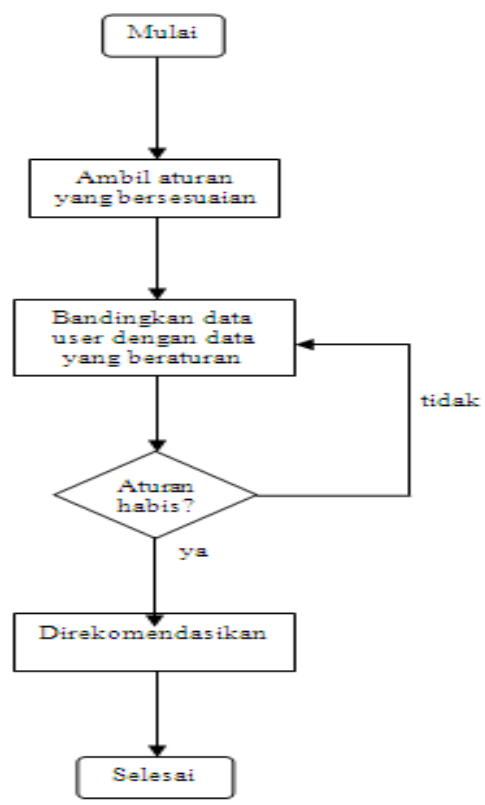

Gambar 2. Diagram Alur Proses Brown Gibson

\section{Data Flow Diagram}

Data flow diagram merupakan gambar sis-tem secara logika yang digunakan untuk me-ngetahui berbagai data yang mengalir antar proses dalam suatu sistem. Dengan adanya gambaran sistem dalam bentuk data flow diagram akan mempermudah dalam mela-kukan penelusuran jika terjadi kesalahan, serta membantu proses pemahaman sistem.

\section{Context Diagram}

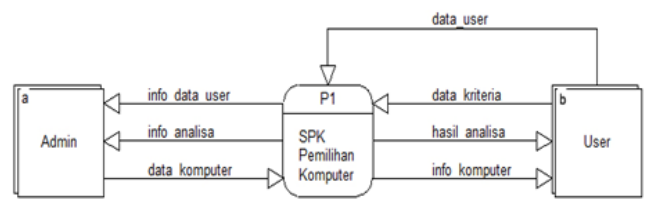

\section{Gambar 3. Context Diagram}

Context Diagram dari alur Sistem Pen-dukung Keputusan Pemilihan Komputer de-ngan Metode Brown Gibson. Di sistem ini terdapat entitas admin dan user yang berhubungan langsung dengan Sistem Pendukung Keputusan Pemilihan Komputer dengan Metode Brown Gibson. Pada user, data yang diinputkan berupa data user dan data kriteria. Sedangkan dari sistem, user mendapatkan hasil analisa dan info komputer. Pada entitas admin, sistem memberikan info user ke admin.

\section{Data Flow Diagram (DFD)}

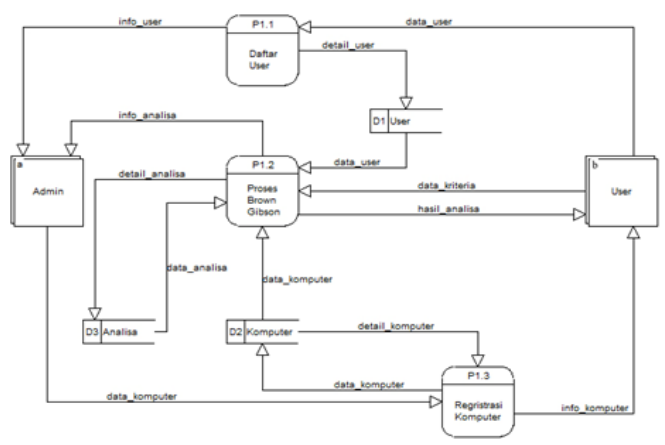

Gambar 4. Data Flow Diagram

Pada Data Flow Diagram (DFD), Context Diagram akan dipecah menjadi 3 tahapan yaitu Daftar User, Proses Brown Gibson, dan Registrasi Komputer. Hal ini bertujuan untuk memudahkan dalam mengetahui tahapan apa saja yang ada di dalam sistem ini. Data komputer akan diinputkan dan di edit melalui admin. Setelah itu barulah user dapat masuk kedalam sistem setelah meng-inputkan data user. 


\section{Entity Relationship Diagram (ERD)}

Entity Relationship Diagram (ERD) adalah suatu diagram yang berisi komponen kom-ponen himpunan entitas dan himpunan relasi. ERD pada sistem pendukung keputusan pemilihan komputer ini adalah sebagai berikut:

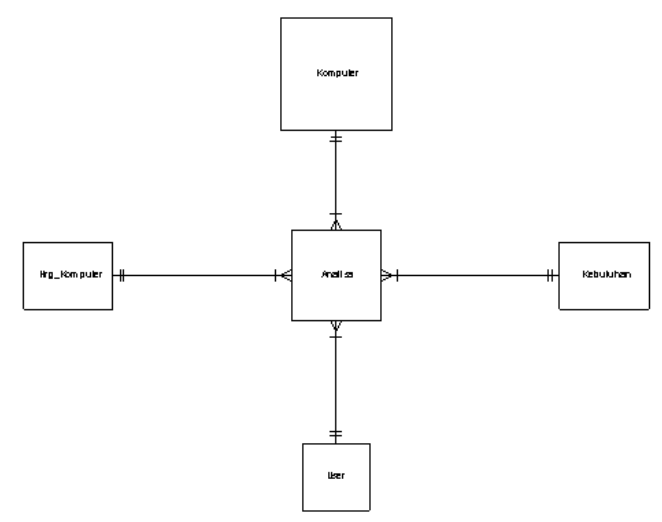

Gambar 5. Entity Relationship Diagram

\section{Konseptual Database}

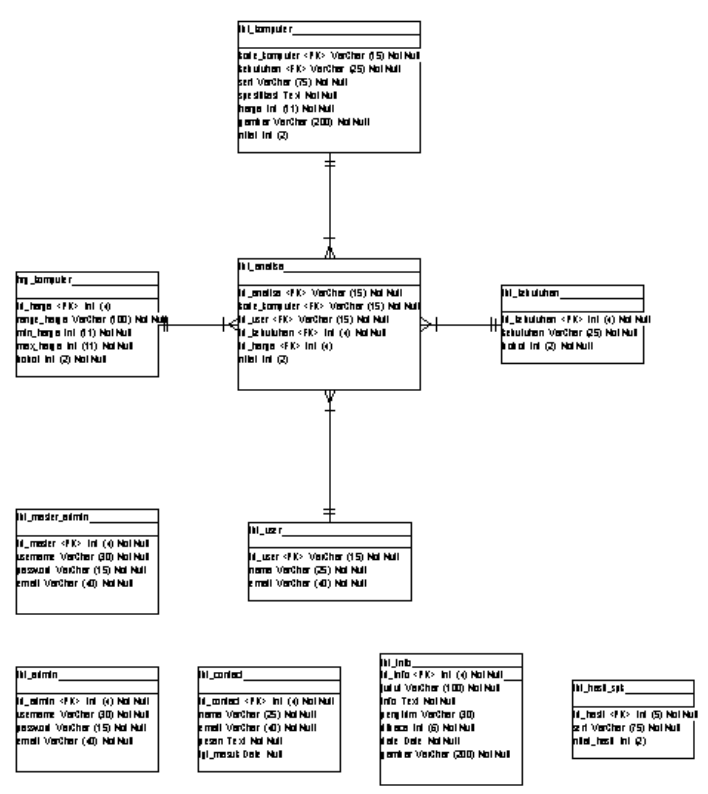

Gambar 6. Konseptual Database

\section{HASIL DAN PEMBAHASAN}

\section{Kebutuhan Sistem}

Pemrograman web yang dibangun telah diuji cobakan dengan spesifikasi perangkat lunak (software) dan perangkat keras (hardware) sebagai berikut : (1)
Sistem Operasi dan perangkat lunak : Sistem Operasi Windows XP / Windows Vista / Windows 7, Macromedia Dream-weaver 8, XAMPP, Adobe Photoshop CS2, Mozilla Firefox; (2) Perangkat keras : Intel Pentium Dual-Core,Harddisk $80 \mathrm{~Gb}$, Me-mori DDR2 $1 \mathrm{~Gb}$, Monitor LCD 14 Inch, Mouse, Keyboard dan Printer.

\section{Implementasi}

Menu utama Sistem Pendukung Keputusan Untuk Pemilihan Komputer dengan Metode Brown Gibson yang ada di ha-laman utama (index) adalah sebagai berikut : (1) Menu Home (2) Menu Info (3) Menu Profil (4) Menu SPK (5) Menu Contact.

\section{Halaman Utama (Index)}

\section{Halaman Home}

Halaman Home, merupakan hala-man yang pertama kali muncul pada saat masuk ke website Sistem Pendukung Keputusan Untuk Pemilihan Komputer Dengan Metode Brown Gibson. Pada halaman ini berisikan tombol Home, Info, Profil, SPK, dan Contact.

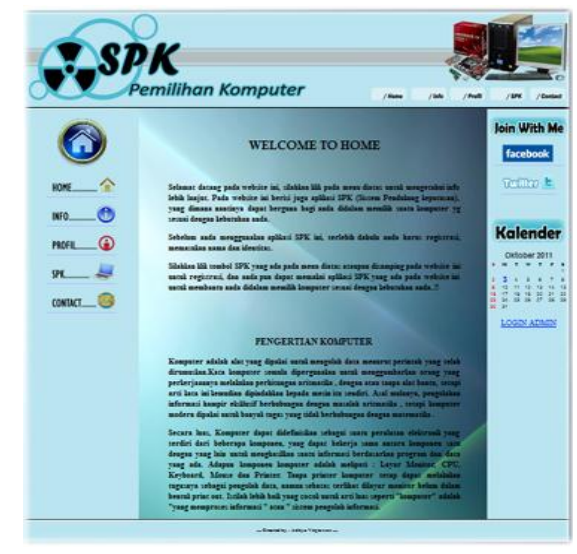

\section{Gambar 7. Halaman Utama (Index)}

Halaman ini merupakan tampilan awal pada saat user pertama kali masuk kedalam website Sistem Pendukung Keputusan Pemilihan Komputer ini.

\section{Halaman Info}

Halaman ini terdapat info-info terkini seputar perkembangan teknologi komputer dan akan terupdate secara berkala. 


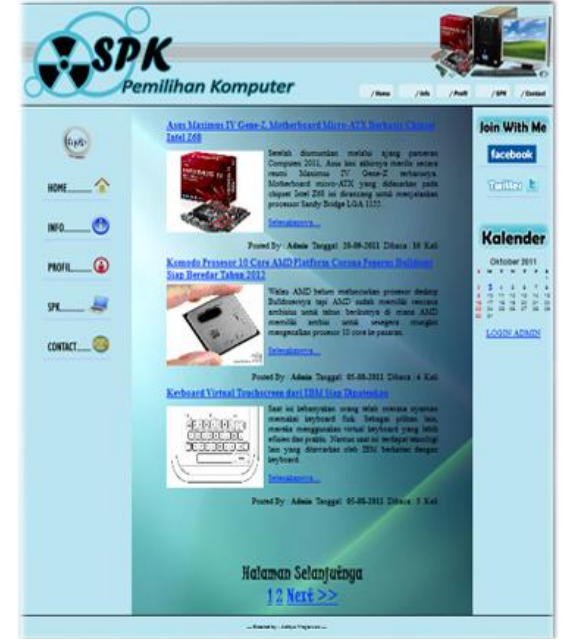

Gambar 8. Halaman Info

\section{Halaman Profil}

Pada halaman ini terdapat profil website serta penjelasan tujuan website ini dibuat. Dalam halaman awal ini berisi sedikit petunjuk penggunaan aplikasi Sistem Penunjang Keputusan untuk pengguna awal.

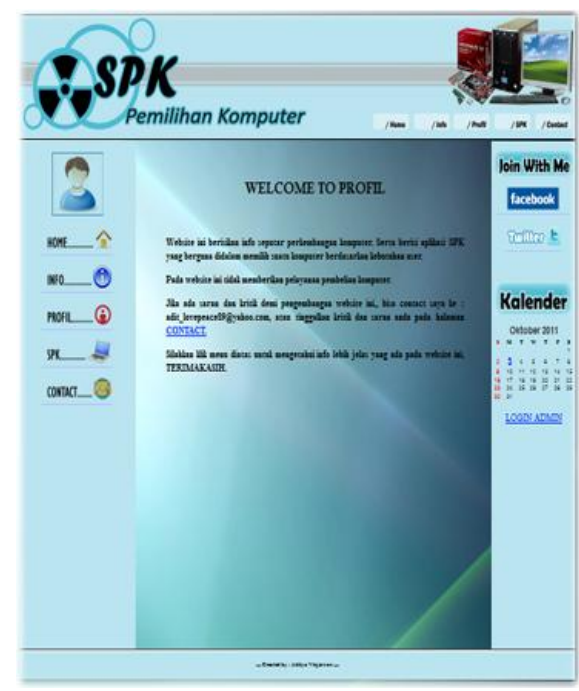

\section{Gambar 9. Halaman Profil}

\section{Halaman Contact}

Pada halaman ini pengunjung (user) dapat mengisi form contact untuk memberikan pesan dan saran kepada admin. Sama halnya seperti buku tamu, user bisa memberikan saran maupun kritik pada form ini.

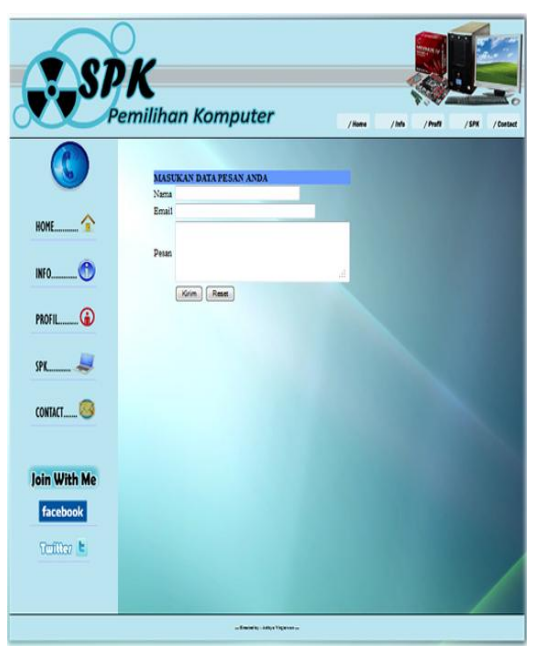

Gambar 10. Halaman Contact

\section{Halaman SPK}

Halaman SPK ini dapat diakses setelah user melakukan daftar user terlebih dahulu sebelum masuk kedalam sistem ini. Halaman ini menampilkan pilihan berapa kisaran harga / budget dan berdasarkan kebutuhan user di dalam membeli komputer, dari hasil pilihan berikut kemudian disimpan dan dicocokan sehingga menghasilkan keputusan beberapa komputer bagi user yg sesuai dengan pilihan user.

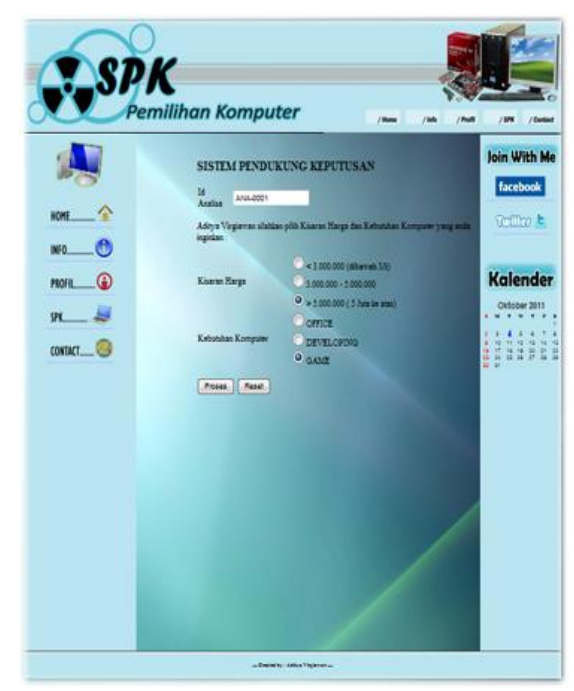

\section{Gambar 11. Halaman SPK pertama}

Halaman web diatas, menampilkan pertanyaan berupa budget dan kebutuhan prioritas user tersebut didalam membeli suatu komputer.I 


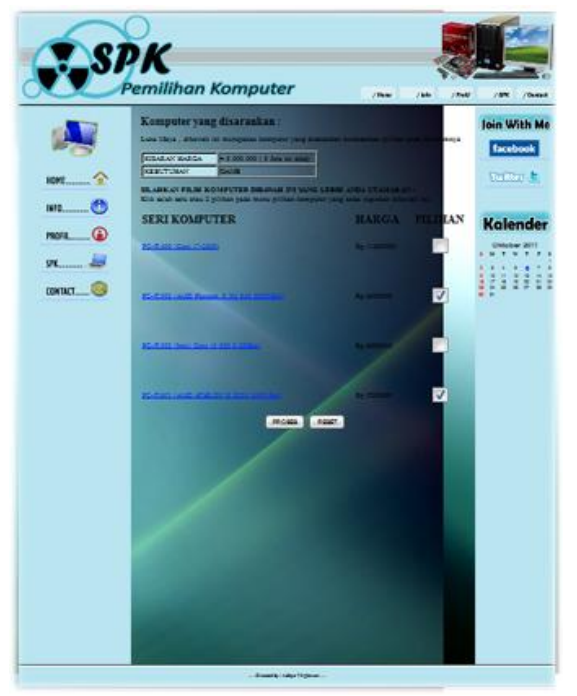

\section{Gambar 12. Halaman Konsultasi Kedua}

Pada halaman diatas, menampilkan beberapa pilihan komputer berdasarkan pilihan budget dan kebutuhan user sebelumnya. Halaman ini menampilkan pilihan berapa kisaran harga / budget dan apa kebutuhan user dari pertanyaan - pertanyaan seputar pembelian komputer berdasarkan kebutuhan konsumen,

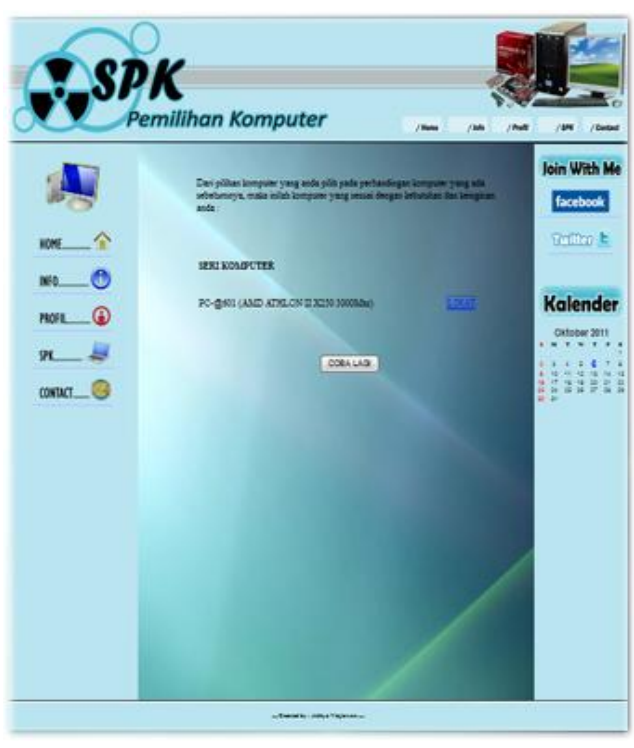

\section{Gambar 13 Halaman Hasil Keputusan}

Pada halaman diatas, menampilkan hasil keputusan dari Sistem Pendukung Keputusan Pemilihan Komputer yang akan direkomendasikan kepada user.

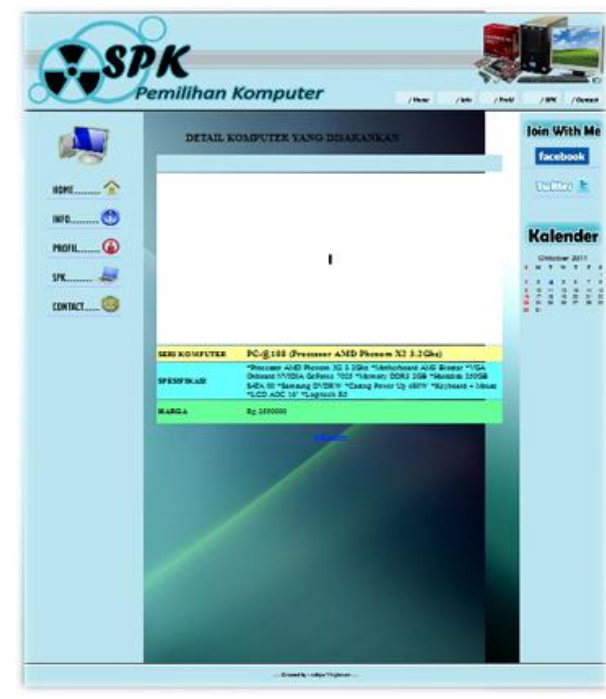

\section{Gambar 14. Halaman Lihat Hasil Keputusan}

Halaman web diatas menampilkan data hasil komputer atau aksesoris yang terpilih secara detail dari Sistem Pendukung Keputusan Pemilihan Komputer yang direkomendasikan kepada user.

\section{Halaman Daftar User}

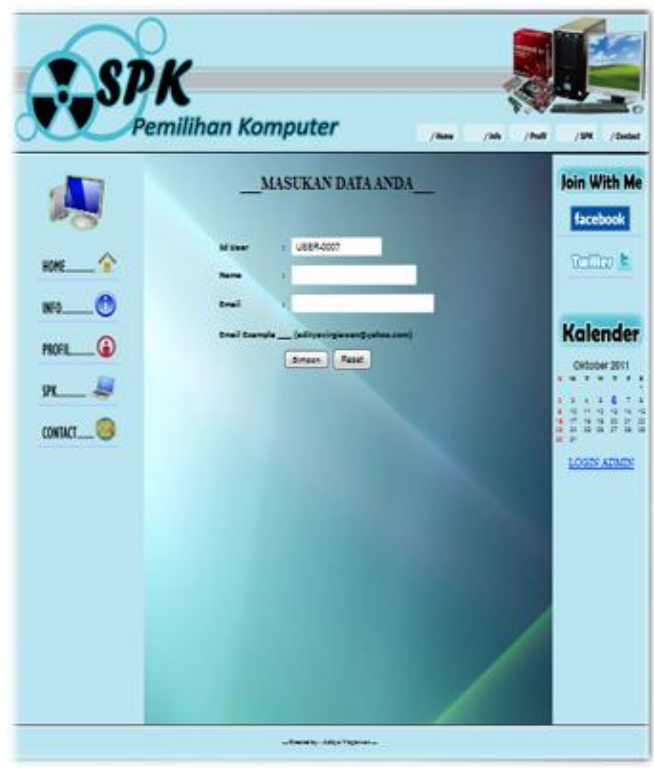

\section{Gambar 15. Halaman Daftar User}

Di halaman ini pengunjung (user) disajikan form pendaftaran diri sebelum masuk ke dalam sistem pendukung kepu-tusan. Dimana data yang harus diinputkan oleh user diantaranya nama, dan email. Data ini akan tersimpan, sehingga user dapat melakukan pemilihan komputer. 


\section{Halaman Utama (Admin)}

Menu utama Admin Sistem Pendukung Keputusan Untuk Pemilihan Komputer Dengan Metode Brown Gibson yang ada di halaman utama (index) adalah sebagai berikut :

(1) Menu Home (2) Menu Admin Manajemen (3) Menu User Manajemen (4) Menu Info Manajemen (5) Menu SPK Manajemen (6) Menu Contactl Data Buku Tamu (7) Logout.

\section{Halaman Menu Login Administrator}

Dalam menu login administrator ini terdapat dua buah pilihan yang dapat diakses, admin bisa memilih menjadi master admin, atau admin.
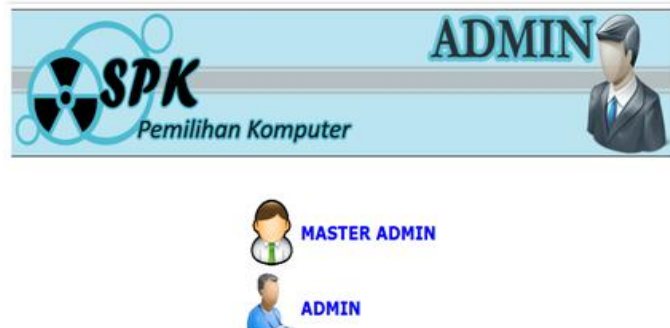

WELCOME TO ADMIN....

\section{Gambar 16. Halaman Menu Login Administrator}

Dimana pada masing-masing menu memiliki hak akses yang berbeda didalam mengatur data-data yang ada pada panel administrator.

\section{Halaman Login Master Admin}
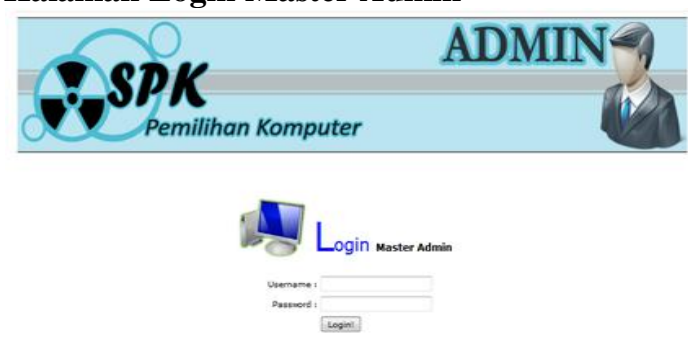

WELCOME TO ADMIN

\section{Gambar 17. Halaman Login Master Admin}

Untuk dapat masuk ke halaman panel admin, maka admin diharuskan login terlebih dahulu, jika ada permasalahan username atau password yang dimasukkan tidak sesuai de-ngan data yang tersimpan maka akan tampil pesan error, dan bila username dan password benar maka akan masuk ke halaman utama administrator.

\section{Halaman Utama Administaror}

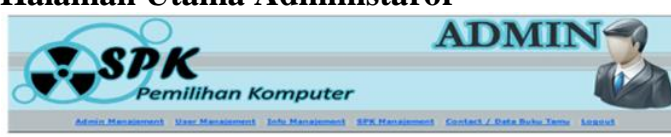

Welcome Admin

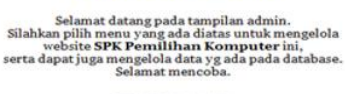

TERIMAKASH

\section{weloome то admin.
Gambar 18. Halaman Utama} Administrator

Halaman utama administrator merupakan halaman home yang tampil apabila admin sudah melakukan login. Untuk selanjutnya admin bisa melihat dan mengatur data-data yang ada pada masing-masing menu diatas.

\section{Halaman Admin Manajemen}

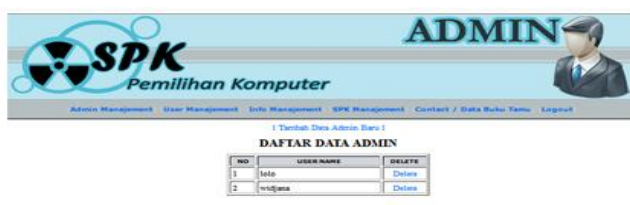

\section{Gambar 19. Halaman Admin Manajemen}

Pada halaman admin manajemen merupakan halaman untuk melihat data admin yang sudah melakukan pendaftaran sebelumnya untuk menjadi admin pada sistem ini. Dimana pada halaman ini admin bisa menambah admin baru, maupun menghapus data admin yang ada. 
Halaman User Manajemen
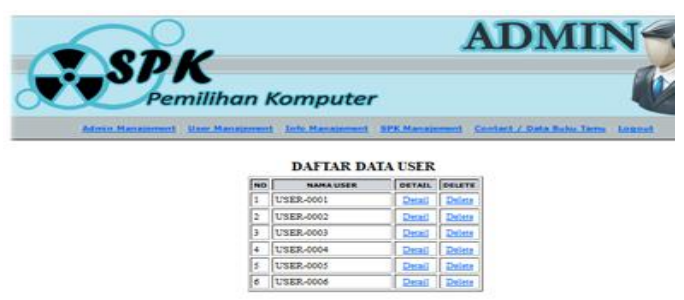

WELCOME TO ADMIN.

\section{Gambar 20. Halaman User Manajemen}

Pada halaman user manajemen merupakan halaman daftar user yang sudah melakukan pendaftaran sebelum meng-gunakan sistem pendukung keputusan ini, dimana admin dapat melihat dan menghapus data user yang sudah melakukan pendaftaran diri sebelumnya.

\section{Halaman Info Manajemen}

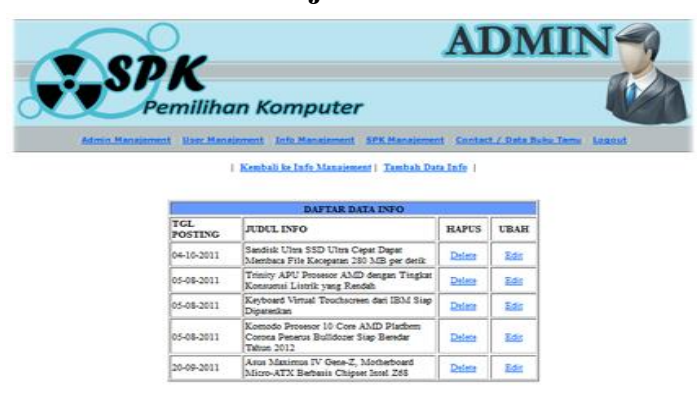

WELCOME TO ADMIN.

Gambar 21. Halaman Info Manajemen

Pada halaman info manajemen merupakan halaman untuk mengedit, menghapus, maupun menambahkan suatu data info baru yang dilakukan oleh admin yang nantinya akan muncul pada menu info user.

\section{Halaman SPK Manajemen}

Pada halaman web ini, merupakan halaman web khusus admin untuk mengatur data data yang berkaitan pada proses SPK komputer pada sistem ini.

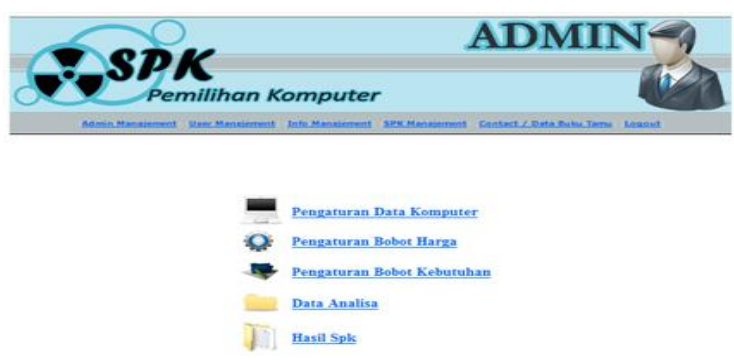

WELCOME TO ADMIN.

\section{Gambar 22. Halaman SPK Manajemen}

\section{Halaman Data Komputer}

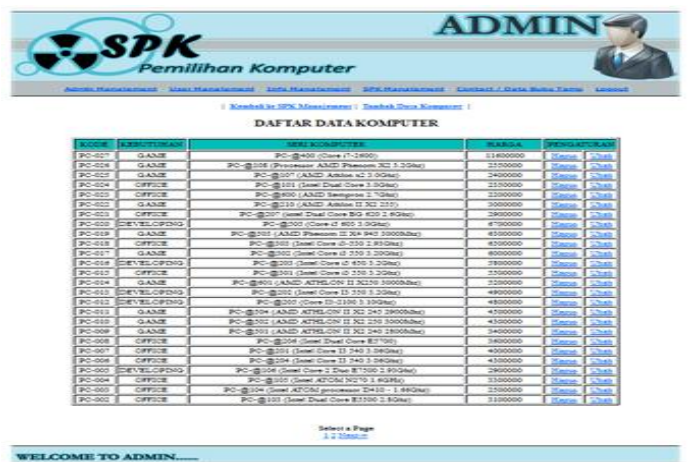

Gambar 23. Halaman Data Komputer

Pada halaman ini terdapat data komputer yang dapat diedit, dihapus, maupun ditambah data komputer yang baru.

\section{Halaman Contact / Data Buku Tamu}

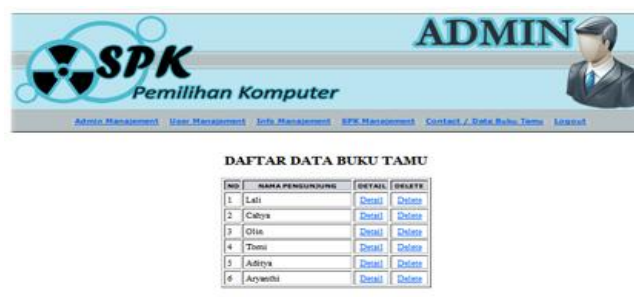

WELCOME TO ADMIN .

\section{Gambar 24. Halaman Contact/ Data Buku} Tamu

Halaman web ini berisi informasi dari user yang mengisi form contact atau buku tamu. 


\section{SIMPULAN}

Dari hasil perancangan dan pembuatan sistem pendukung keputusan ini diperoleh kesimpulan bahwa Web cukup berguna sebagai sarana dalam pengambilan keputusan pembelian komputer. Fasilitas sistem pendukung keputusan ini mampu membantu kon-sumen dalam pemilihan komputer yang berkualitas dan sesuai dengan kebutuhan serta budget yang dimiliki oleh konsumen. Sistem berbasis web ini, mempermudah para user dalam memperoleh informasi dan mengakses data secara online.

\section{DAFTAR PUSTAKA}

[1] Jogiyanto. 1989. Analisis dan Desain Sistem Informasi. Yogyakarta : Andi offset

[2] Kadarsah dan Suryadi. Sistem Pendukung Keputusan. Bandung : PT Remaja Rosdakarya

[3] Bunafit Nogroho.2006. Membuat Aplikasi Penjualan dengan PHP \& MySQL. Yogyakarta : Ardana Melia

[4] Hassan, I. 2002. Pokok-Pokok Materi Teori Pengambilan Keputusan. Jakarta : Ghalia Indonesia.

[5] Kendall-Kendall. 2003. Analisis dan Perancangan Sistem Edisi Kelima. Jakarta : PT Prenhalindo

[6] Syafii M. 2004. Membangun Aplikasi PHP dan MySQL. Yogyakarta : Andi

[7] Ammarapala, Veeris, dan James T.Luxhoj. 2000. A Review of the Brown-Gibson Model for Multiattribute Decision Making 